\title{
The Political Theology of Violence in Contemporary India
}

Thomas Blom Hansen

\section{(2) OpenEdition}

\section{Journals}

\section{Electronic version}

URL: http://journals.openedition.org/samaj/1872

DOI: $10.4000 /$ samaj. 1872

ISSN: 1960-6060

\section{Publisher}

Association pour la recherche sur l'Asie du Sud (ARAS)

\section{Electronic reference}

Thomas Blom Hansen, « The Political Theology of Violence in Contemporary India », South Asia

Multidisciplinary Academic Journal [Online], 2 | 2008, Online since 31 December 2008, connection on 19 April 2019. URL : http://journals.openedition.org/samaj/1872 ; DOI : 10.4000/samaj.1872

This text was automatically generated on 19 April 2019

\section{(c) $($ i) $(9)$}

This work is licensed under a Creative Commons Attribution-NonCommercial-NoDerivatives 4.0 International License. 


\title{
The Political Theology of Violence in Contemporary India
}

\author{
Thomas Blom Hansen
}

1 What are we to make of the fact that most violence in India is rarely presented, or rarely presents itself, through visible actors, or through people taking responsibility for bombs, riots, arson and looting? ${ }^{1}$ Why is most violence represented by the police, by political parties and by those perpetrating the violence as a form of spontaneous combustion expressing seething anger, collective outrage and a deep sense of hurt? Why are bomb blasts, mob violence, arson and other atrocities happening without anyone claiming responsibility afterwards, without anyone providing justifications? Why are violent acts portrayed neither as homicides nor crimes but instantly metaphorized as expressions of collective emotions? In a country so saturated in political rhetoric it seems paradoxical that acts of violence have acquired their own semiotic register, a singular form of political 'communication'. What is the cultural logic of this portrayal of violence as quasinatural events without actors?

2 I use the term political theology as a reference to Carl Schmitt's problematic yet insightful idea of the decision as the heart of political life. Schmitt suggests that 'the analogy of the miracle in theology is the exception in jurisprudence' (Schmitt 1922: 9). His discussion centres around a neo-Hobbesian interpretation of the state as founded on violence and the capacity to decide on the norm-politically and legally - that is the 'miracle' in political life, the omnipresence of the state as a deus ex machina, an entity that becomes surrounded by magical properties because of its ultimate control of violence and its capacity to authorize (arbitrary) definitions of the normal, and to decide on the suspension of the law in a state of exception. ${ }^{2}$

What I mean by political theology of violence here is something related, yet slightly different: how acts of violence are interpreted and understood as signs of something else standing behind it; a sovereign will, a collective force of outrage and anger, a historical revenge, or even the 'hand of God'. This is pertinent in the context of India because violence-acts of terror or 'faceless' mob violence-is so often interpreted as quasi natural 
reactions, as actions without actors. This is akin to the staging of acts of terror as 'pure effects' that are only attributed causes and reasons after the fact, as Faisal Devji puts it in his work on Jihadist thought (Devji 2006).

\section{Crowd violence, the unknowable monster}

4 It has been demonstrated very well by Gyan Pandey (Pandey 1990) that the colonial idea of the crowd in India was one of a faceless, aggressive, unfathomable, irrational compact of people in the thralls of religious passion and beyond the comprehension of colonial sociology. The explanations of riots varied from religious fanaticism gripping the great unwashed, to instigation by the habitual criminal, the badmash, or to instigation by people with political agendas-educated and respectable people who had turned into dangerous political activists. The effects were dangerous and destructive crowds that had to be dealt with through overwhelming and resolute force. The manuals of policing of the colonial state spoke at length about the need for an extraordinarily firm hand in the East (Chandavarkar 1998).

5 This style of policing, and the view of crowds as a destructive, wild power rising from the people, still prevails in the legal system, in the police academies, and in police compounds. In this view, crowds are faceless, have an almost magical form of agency that cannot be accounted for or fully understood-just met with overwhelming force. No individual culpability is normally attached, or sought, even in cases of extensive crowd violence. ${ }^{3}$ The cult of the 'super cop', the man of steel cleaning up ubiquitous dirt and corruption is well and alive in modern India. The proliferating crime channels on Indian TV channels tend to reproduce and reinforce the notion of the men in khaki as a thin brown line defending respectable society against its enemies.

6 Among many poor people, similar perceptions are often heard: riots or marches are organized by 'political people', by troublemakers, by criminal elements and so on. However, there is also a widespread endorsement of such actions-that outrage, anger or frustration somehow naturally manifests themselves in crowds that can easily turn irate, and commit acts of violence and destruction. Collective outrage, anger and political passions are emotions that routinely are accepted to be beyond reason and civilized discussion and they are, indeed, deeply legitimate forms of political expression in India.

7 There are limits, however, and for most people the killing of someone in a political protest almost invariably marks a critical threshold that changes everything. Protests against officialdom, even the wrecking and destruction of public property, are widely considered legitimate-not desirable but understandable. A death caused by reckless firing by police officers on a crowd or people protesting can, in most cases, produce a legitimate martyr in the wider public. The main exception to this rule is that of Muslims and tribal communities where deaths at the hand of the authorities are usually portrayed in the wider public as self-inflicted and fully deserved results of extreme aggression. Muslims and Tribals are seen as martyrs within their own communities but not in the wider political community.

8 In the case of communal violence during riots, the moral value of death is rather different. The killing of an individual from another community in the context of an allout confrontation in streets and neighbourhoods is abundant with significance. The category of 'the other' almost invariably overshadows the identity of the individual. Riot 
situations suspend most parameters of appropriate behaviour, proportionality and justice. Instead, intense feelings of fear, anger and revenge take over along with forms of wild enjoyment, exhilaration, shame and guilt.

9 There are in other words, two categories of public violence-both of which mark a breaking of a norm and the creation of an exceptional situation, both of which are widely endorsed and perfectly legitimate elements of political life in the wider population.

The first, and by far the most widespread and routinized form of public violence, is protests against the state, or any kind of official, by crowds gathering, pelting stones, attacking and destroying public property. How did this become a form of legitimate and deeply routinized violence? I can think of three reasons:

1. The legacy of the anti-colonial struggle created political languages and forms of manifestations that are still alive and have been enormously revived in the 1970s protests against the state and Indira Gandhi's increasing centralism. Today, the register of public protests, of breaking the law peacefully-the dharna, the rasta roko, hunger strikes, etc.are deeply embedded, even banalized, across the Indian political landscape as a set of possible languages of political expression and dissent.

12 As we know, Gandhi skilfully recruited and mobilized the visceral power of the crowd and the moral purity of communities formed in opposition to unjust rule. But it was always a precarious balance, always a knife's edge balancing between peaceful protest and all out communal killings, as in the 1920s, and in Bengal in the 1940s at the eve of independence.

13 After independence, the state was suddenly a national state in the hands of a new national elite but the language of public protest prevailed. The difference was now that the police had to restrain themselves, and that the moral force of such anti-government crowds were of a different nature. Yet, the Gandhian ethos persisted and turned into maybe the most legitimate of all public actions in modern India: the anti political register that opposes the state or officialdom, or corruption, by disavowing 'power politics' and representing the purity of the people, as condensed in the austere and self-abnegating body of the hunger striker, or the political ascetic who invariably disavows politics and calls himself a social worker.

A socialist /Gandhian member of the West Bengal assembly stated in 1955:

As regards to laws, I would like to mention with all humility that under the leadership of the father of the nation we have been taught to break lawless laws, and we will need to break laws again.... To us life is more precious than legal forms... We may be tear-gassed and there might be lathi charge, but it is a legitimate action to commit satyagraha. In a demonstration the people must have the right to violate the law. Peacefully, of course. If there is violence, it is because the government acts violently, not the people.

In this rendition, which could have been spoken last year, the state and not the people is the source of violence. The community, the people (samaj, log), are pure at heart, are not infected by 'bad' self-interested electoral politics, their anger is always legitimate and righteous. This is the repertoire of 'anti-politics' at its purest. This principle of legitimate protests has long been established in modern Indian public life, to the point that such public violence is now routinized as one of the most legitimate and expected forms of political action.

16 2. The second explanation is that public violence is a form of collective catharsis. The highly ritualized negotiations between crowds and officials representing the state are a 'political good' that Indian democracy has made available to ordinary people, a safety 
valve that involves periodical public humiliation of public officials. This is a thesis that Dipesh Chakrabarty has put forward in a recent paper (Chakrabarty 2007). He suggests that a mutual ritual economy has developed between local communities and state officials. For local people, there is the satisfaction of forcing high-ranking officials to eat humble pie, to apologize in public, and to promise to improve services or rectify an error. After an apology has been issued by the official, the crowd will disperse, and the short lived experience of being 'the people, or 'the public' representing society, of occupying the moral high ground as legitimate political actors come to an end. In most cases nothing happens, however, until the next protest, and another officer in charge is transferred.

There is in this a strong element of the 'leveling' that Tambiah analyzes in his book on crowd violence; the pleasure of immersing one self in a crowd and to make a feared and powerful opponent fear you, to reduce him/them to the same level as yourself (Tambiah 1996). On the side of the officials, it is a well-known fact that being an officer in charge may involve periodical displays of humility before angry crowds. It is regarded as merely an unfortunate circumstance, a part of the environment, but also something that can be dangerous if politicians interfere or force transfers. Most judicious bureaucrats are well aware of the need to go along with this ritualized exchange of protest, humiliation and apologies.

It would be tempting to look at this as a ritual cycle through Victor Turner's template of the dialectic between the norm and its temporary suspension. To Turner, the intense form of communitas experienced through rituals serve to renew and re-integrate social compacts and relationships (Turner 1974). However, our third possible explanation, which I will call the imperative of visibility and improvised performance, seems to foreclose such functional explanations.

19 3. One of the most compelling dynamics of democracy is that it foregrounds representation and visibility. A community, a cause, a grievance, a feeling of hurt and outrage must be made visible and audible-it must be enacted in public to be recognized as real and compelling. The noise and destruction of property by a crowd is, in other words, a necessity for those who want to project themselves as angry in order to seek public recognition of this anger. The violent act is thus always interpreted as a sign of something else, something bigger than itself. Yet, the crowd is also something in its own right-unpredictable, unstable, slightly out of control and thus open to many interpretations.

Staging collective anger and outrage through public violence is always a risky if not dangerous game for movements and individuals, a game where one risks forfeiting goodwill and legitimacy. Yet performing public violence is at the same time imperative if one is to demonstrate and perform the depth and authenticity of the anger and resentment that a movement, or party, claims to represent. In my earlier work I quote a somewhat comical instance of this imperative of violent action when a Shiv Sena Mayor reacted against the arrest of Bal Thackeray by the state authorities by leaving his mayoral office, only to lead a crowd that in turn attacked and burned his own office in Thane city (Hansen 2001: 227)!

21 But let us move to the second kind of violence I mentioned above, the communal crowd violence. Here, another, more dangerous, and more ambiguous moral game is played out. 


\section{Crowds and fire in India} connected with the growth of Hindu nationalist sentiments. Of these organizations, the Shiv Sena in Western India is undoubtedly the most violent, plebeian and visible. This organization has the tiger as its symbol and its imagery revolves around strength, masculinity and the lack of fear. While it began in the 1960s as an organization defending the Maharashtra dharma and the interests of Marathi speakers in the city of Bombay (Katzenstein 1979; Gupta 1982), the organization has in the past decades styled itself as the 'fighting arm' of the Hindu community. It glorifies the sainik, the soldier, as someone who is in the thrall of his passions and his sense of natural justice-an elemental desire to seek justice on the part of his community, to defend his family and neighbourhood. These men, and their passions, may not be pure but their actions are purifying and cleansing acts.

The theme of fire is at the heart of ideas of both passion and violence across the world. In India, fire is possibly one of the densest cultural metaphors one can think of. In established Hindu cosmology, fire signifies transformation from one state to another, a pure connection as represented by the god Agni, But it also signifies death and annihilation, as well as the sacred in ubiquitous forms-from the temple fire, the lamp ( jyoti) to the fire used at marriage ceremonies (nikah) and so on.

In a strict physical sense, fire is ontologically empty. There is no substance or unity to fire, fire is only transformation that acquires specific colour, duration and heat from the materials burning. Fire is at its purest, most transformative and warmest at the top, while always dirtier and emitting ashes and debris at the base (Bachelard 1987).

The notion of fire as pure transformation, a power that is both ephemeral and fundamentally transformative, is at the heart of much religious imagery. Jahve makes himself known to Moses in the desert in the form of a burning bush, and in the Hindu mythology the god of fire, Agni (which shares the linguistic root with ignis in Latin), is immensely powerful. Always mobile and on the move, mounted on a ram, or in a chariot pulled by goats, Agni is the link between gods and men, and he is also the messenger between the gods. He is ever young, reborn and relit every day and thus immortal, and omnipresent-both in the heavens and in every person where he lightens the small flame of being, as in every living thing.

Agni is prominent in the ancient $R g$ Veda and was for centuries worshipped by warriors and cults devoted to strength and virility. The use of fire became especially popularized in the $20^{\text {th }}$ century by the Arya Samaj, a modern Hindu reform movement. For the Aryas, fire was less about Agni in his elaborate mythological form. They were more concerned with fire as a metaphor of the sacred as such, as the centre of the hawan ceremony, the key element in the Arya Samaj's attempt to create simplified, portable and yet dense basic Hindu rituals.

27 As we know, fire has another important function in India, namely the funerary rites. When a person dies, the flame is extinguished and as soon as that happens, the corpse of even the purest Brahmin becomes radically impure, only to be handled by the specialized 'untouchable' castes dealing with funerary rites. When the body is placed on top of the fire and the fire is lit, it becomes a sacrifice to Agni and the body is once again

South Asia Multidisciplinary Academic Journal, 2 | 2008 
transformed into a migrating soul rising above the pure, and the waste, the ashes and the remains that are still impure, deposited into the sacred river. This is purification and 'distillation' of the spirit in a very direct and tangible form (Parry 1995).

The notion of spontaneous anger and direct display of passion through 'direct action' is central to the image created by Shiv Sena over the years. One of the movement's slogans goes like this: 'A Shivsainik is like a burning torch. He shall burn the evil and he shall also show the path of life to those who struggle in darkness'.

The movement's longstanding dictatorial leader Bal Thackeray always framed himself as the man with guts and ability to speak the truth, to defend the Hindus. For him Shiv Sena was nothing but an expression of the Hindu will. There was nothing particularly religious about his view. One of his saying is: 'We are Hindustanis and therefore Hindus. We love Hindustan more than ourselves'. To him, the love of the nation was all about spontaneous gut feeling; dil se-from the heart. This passion was more in the sainiks than their own will and it made them do things that would be considered transgressive, but actually were pure because there is purity in the authentic passion-it takes you over, becomes you more than yourself. The numerous attacks on Muslims and other minorities by this movement over the years have invariably been justified as 'spontaneous reactions'; as defence against a threat, or as the justified wrath of the community. A local Shiv Sena leader told me the following:

If you do not allow me to speak how am I to express myself? I am not a beggar and no doubt I also have some respect. There is also nature's law and I can also use that ... The principle of natural justice is accepted by us and this is the principle of natural justice-whatever is mine is mine and whatever is yours is yours... It is just like playing with fire. If you sit beside it, it will warm you, but if you play mischief with it, it burns your house. Shiv Sena is like that.

As mentioned above, colonial and contemporary policing in India regarded crowds as semi-sovereign entities in that they could be dispersed and controlled as collective entities, but individuals were never held accountable for violence or destruction in the course of crowd action. To kill in a crowd is, in effect, to kill with impunity. Staging crowd action as an expression of authentic public emotion and outrage is one of the oldest and most sophisticated political technologies among political activists across the Indian subcontinent. This has to do with the registers of public legitimacy of collective action within the postcolonial democracy I discussed above, but it also has to do with the obvious attractions, if not enjoyment, associated with crowd action.

31 To enter a crowd is to enter a momentary space of exception where normal rules of behaviour and conduct are suspended for a time and other rules and norms prevail in the moment of effervescence. This can be true of a crowd carefully staged for political purposes, a spontaneous crowd gathered around a protest or an incident, or even the destructive and enjoying football crowds described by Buford (1990). Not all crowds are violent but once a crowd explodes in anger the 'other' is no longer a feared enemy but is turned into 'bare life'-a de-symbolized form of life that can be killed with impunity and upon which the sovereignty of the crowd, and the community it claims to represent, can inscribe itself (Agamben 1998). Crowds are not merely ruled by anomalous and primitive instincts as Le Bon and Freud held. Crowds are, as Tambiah points out in his admirable synthesis, often driven by a search for the 'enemies' and their property which it seeks to destroy and level, but also to devour 'in an almost cannibalistic fusion of self and other' (Tambiah 1996: 275). 
ds engage in destruction of public property and often in stylized confrontations with the police that take the place of 'the enemy'. The clue to an understanding of the sovereignty of the crowd, however, short lived and passing it may be, lies in what Tambiah in passing calls the 'substantialization' that often evolves in a crowd (Tambiah 1996: 219). Tambiah understands this as the concretization of identity and community. But it is also possible to link this to the visceral economy of the physicality of the crowd: the sense of loss of bodily autonomy and the experience of a co-substantiality that lead crowds to become 'spaces of exception'-not with a single mind, but fleetingly unified by a momentary sense of bodily authenticity, certainty and exhilaration-driven by what Elias Canetti calls a crowd's 'love of density', and therefore an entity without doubts or fear. Maybe we can expand Appadurai's idea of ethnic violence as being driven by a search for certainty in the body of 'the other' (Appadurai 1999) by recognizing that there is also certainty and authenticity to be found in the visceral-physical compact of the crowd.

Although the Hindu nationalist movement has extended the logic and justification of crowd violence to become an index of community sovereignty, the use of the crowd and its violence as a legitimate political expression of anger and sovereignty is extensive across the political spectrum in contemporary India. As a repertoire of authority and moral argument, 'community' is very powerful indeed qua its historical connotations of delineating a measure of 'collective privacy', and qua its incorporation of issues of honour, family, bodies and reproduction. Most of the language of social reform through law-reservations of jobs, constituencies, and educational opportunities-have also been framed and justified in terms of collective predicaments of communities. ${ }^{5}$

Some political leaders talk about these events as the 'opening of Shiva's third eye', the ominous event that will happen in times of great danger, an event that inaugurates annihilation of the enemy. The king/leader thus makes himself into a tool of the divine, the absolute, turning himself into God's hand, and fire moves to the centre, once again, as that universal and impersonal force that wreaks destruction and death. Fire may be ignited by someone but once it is going, it is a force in its own right, more in us than ourselves-something that is alien and yet overtakes us (like the drives in Freud's writings), it is a force that exists in the community as a potentiality-but never identical to it. Fire is a paradoxical form of empty agency. Once fire gets going, it is a pure effect, lacking specificity or ontology and yet behaving as a type of autonomous agency-a pure transformation of something into nothingness.

In Violence and the Sacred, Rene Girard writes about the king, the fire and the absolute:

The king is both very 'bad' and extremely 'good'... the king's subjects may feel ill at ease in his presence, awed by his sheer superabundance of power. Nevertheless, they would be terrified if they were deprived of his presence... The absolute can be likened to fire: too near and one gets burned, too far away and one gets nothing. In between there is a zone where one is warmed and heartened by the welcome light (Girard 1979:111).

In this rendition, fire is metonymically linked to the absolute, a powerful nothingness that is the source of everything. When it disappears, the excitement, the exhilaration and the potential transgression disappear. Let me return to crowds and fire where the motifs of the transgressive and the exciting-which is in us and yet beyond us-are particularly powerful.

South Asia Multidisciplinary Academic Journal, 2 | 2008 

largest riots ever, framed as a Hindu revenge against the Muslim protest against the razing of the Babri mosque in Ayodhya a month earlier. The first round of protests by Muslims mainly targeted the institutions of the state and more than two hundred Muslims were killed, mainly by police bullets. There were also attacks on Hindus and Hindu dominated areas which, in turn, became the cause of the second and much larger round of violence in the beginning of January 1993 where Shiv Sena led and encouraged an all-out attack on Muslim neighbourhoods and businesses across the city. This was framed as acts of war and revenge, as blood for blood, and was provoked by the burning to death of a Hindu family, supposedly by Muslims, in a working class area in the city. ${ }^{6}$ ever experienced. The odd military and police vehicle moved in the streets, and a few taxis, one of them ferrying me. The driver was a middle-aged man, the pale shade on his chin and cheeks betrayed a newly removed beard. Like many other Muslim men, he had shaved off his beard to pass as a Hindu. I, the firangi, was his life insurance it dawned on me. He was quiet, sweating profusely, nervous and tense. We drove slowly following a military vehicle which gave us a vague sense of safety. Streets were lined with men, many of them with sticks, knives, bottles with acid or kerosene, standing, waiting for something, anything to happen. Many young men stood on the roof tops, with saffron flags. Columns of smoke rose from multiple fires in the city. dispersed reluctantly. They stood around a burning car. Inside we could see a body, on fire, twitching violently, then falling. A terrible smell of petrol, rubber and human flesh surrounded us. The men looked excited, some screamed 'Jai Shri Ram', 'Mussulman, Pakistan ya Kabristan' ('Muslims, Pakistan or the graveyard'). Some soldiers got out, and began to disperse the crowd. People only moved reluctantly. The commanding officer called the soldiers back. A few minutes passed, long and tense minutes. The fire died down gradually. A soldier put out the rest of the fire, and the crowd dispersed, silently. The aggression was gone, a new fear crept in. What will the soldiers do? An officer approached me, asked for papers, and passport. I asked him if they will do anything. He shrugged and sighed: 'This is the tenth fire we put out today... what can we do? Arrest the people? Who has started the fire we cannot tell'.

he fire had gone, it had done its work, 'it' had killed another Muslim, but no one was directly guilty. Yet they all were, and the worried grins on their faces seemed to betray this strange guilt. A taboo had been violated, someone had been killed, the tension was relieved in a double sense. When the fire disappeared, the sense of agency also evaporated. As Canetti says in his book Crowds and Power: 'To commit a murder in a crowd, without culpability, seems irresistible to most men' (Canetti 1984:50).

41 However, murder is always impure, hence the great relief to have the impurity burned, leaving no evidence, no direct responsibility; only the effects of indirect and empty agency. The fire can stand in for the passions and aggressions in us-our lower political selves-always disavowed and impure and thus in need of concealment or projection onto an external cause.

Canetti continues:

Fire spreads rapidly; it is contagious and insatiable; it can break out anywhere and with great suddenness; it is multiple, it is destructive... all this is true of the crowd...

South Asia Multidisciplinary Academic Journal, 2 | 2008 
fire is one of the most important and malleable of the crowd symbols.... The human

urge to become fire is still alive in more complex cultures (Canetti 1984: 77).

The army captain was right. A few miles further on, in another neighbourhood, we were forced to stop by a couple of hundred young men in the street. Looting of a row of shops, presumably Muslim owned, was in progress. The mood was exuberant, loud but also nervous and aggressive. A couple of middle-aged men supervised the scene from the other side of the road. One of them came over and asked me questions. I whipped out a couple of visiting cards from prominent members of Shiv Sena I had met recently. One of them read 'To my friend Thomas'. The young men surrounding the car, dispersed when the man said 'he is OK, a friend'. The taxi driver turned around and smiled thinly, as if saying 'phew'!

Suddenly someone threw a burning bottle and fire spread rapidly along the row of shops. The mood became wilder and more exuberant. Young men were dancing, throwing things into the flames. Alcohol was consumed. Boys holding bottles, new shirts, boxes of soap and much else were pacing up and down the sidewalk. We could hear screams from the inside of the shops, and the apartments upstairs. Screams of women and children. The boys kept on dancing and chanting. All of a sudden the local leader turned his attention to me and ordered us to leave, quickly, threatening us, leave, 'no photos... just fuck off. We had witnessed something we should not, a transgression that could no longer be stopped, a complex economy of guilt and a fire completely out of control in more than one sense. The face of the driver was contorted in fear and rage. 'We can't do anything, let us go now', I said in an ineffective attempt to console him.

families and groups inside burning houses and shops-the burning of the taxi driver-as a sacrificial logic? As a purging of evil and danger from within the community, where the victim stands in for the evil and the violence that is intrinsic to the community itself and thus is a constant desire and drive that must be placated? Fire does not just kill, it also purifies, it transforms the impure into the elements. This is the gist of Rene Girard's argument but it seems too functionalist for my taste and does not account for the fact that Muslims and Hindus see each other as utterly alien to their respective communities. The dynamics I observed at close range in Bombay calls for something more-not just a deep culturalist argument about Hinduism and fire-, because this touches a larger and more general question: Why is fire used by crowds, or in ethnic cleansings, in so many parts of the world? What are the performative elements in death by fire?

One answer must be one akin to Bill Buford's observation in his book on football hooliganism: 'I am in the crowd, I am of the crowd, but the crowd is not me' (Buford 1990: 157). Like the crowd, fire is an agency that is nobody's, that belongs to nobody. It can be constructed as a kind of nature unleashed, a representation of a disavowed desire that cannot be spoken, only enacted. Fire creates an event that is of itself, it has its own dynamic and force once it is ignited, yet it is also parasitical on everybody's attention and gaze. It is an anonymous event of eradication of life, things and property, of being-an event that can be owned in different ways by those gathered around it. It becomes a pure effect- i.e. an event without a clear cause which in turn allows for multiple interpretations.

We can think of many such interpretations in a South Asia context-for instance the ritual humiliation involved in actually forcing cremation upon Muslim bodies. One can also read symbolic economies into the burning of things as a way of turning these objects 
or bodies into disposable entities, annoying waste that needs to be cleaned out akin to what happens to clothes coloured by the multiple colours used at the Holi festival; or perhaps akin to the status of the always disposable Dalit body. For the dancing and drinking young men, there was indeed enjoyment, a perverse catharsis and expenditure similar to what Bataille had in mind in his critique of functionalism and utilitarianism: expending energy, enjoyment, destruction of objects by consumption and devouring and even annihilation of life constitute non-rational rationales, if not end-goals of much human conduct (Bataille 1991). Such ambivalent energies and desires that sometimes find an outlet in crowd violence are exactly the raw material which Hindu nationalists have mobilized, staged and given a political direction in the last decades. This became even more apparent in Gujarat in 2002.

\section{Gujarat-transgression and new economies of violence?}

The anti-Muslim pogrom in Gujarat in February-March 2002 was a chilling demonstration of how the RSS and BJP combine the longstanding public repertoires of crowd action as spontaneous combustion with the use of fire as a powerful (non) agent. Fire was the lead theme in these riots, as were the lack of direct agency, the concealment of actors. It was all portrayed as spontaneous reactions, a form of combustion that begins as an explosion in the heart, in reaction to a provocation or deadly threat, then a retreat of reason and restraint, which in turn spilled over into fire and arson, burning and annihilation of the enemies.

The pogrom began with a fire supposedly caused by Muslim attack on a train outside the station in Godhra. 55 Hindu 'temple volunteers' returning from the holy city of Ayodhya (where they had gone to support the controversial Ram Temple project) perished. The subsequent pogrom against Muslims across the state lasted for weeks and left thousands of Muslims dead, wounded and even homeless. The events were justified as a 'natural' reaction of the Hindu samaj as such to revenge the temple volunteers' deaths. As so often before, the Hindu nationalist movement sought to become and embody the community of Hindus by killing its imagined enemies in its name.

But the BJP government in Gujarat also provided crucial conditions for the pogroms by withdrawing or pacifying the local police force and administration. Soon after, the government banned the direct reporting of the riots by privately owned TV channels. Similarly, the central government-also dominated by the BJP-refrained from effective measures for several days, allowing the local units of the RSS and VHP and their many local supporters to wreak deadly revenge on Muslims all over the state. Although an official inquiry into the riots was ordered, BJP asserted the de facto right to kill with impunity in the name of the Hindu community and its disregard for legal procedures by staging a large gaurav yatra (pride procession) in the state in August-September.

The yatra was led by the state's BJP chief minister-who claimed to lead the procession in his capacity as a 'Hindu leader'. Officially, the procession aimed at commemorating the 'Hindu martyrs' of Godhra. However, its route through hundreds of towns in the state, which had been the scene of arson and slaughter of Muslims a few months before, was staged as a celebration of the victory of the Hindu community. This open display of disregard for legality demonstrated that the Hindu nationalist movement continues to 
see itself as representing the sovereign right of Hindus to assert their emotions and religious passions vis-à-vis minorities and perceived enemies. To the BJP, the control of state power meant that it could stall the assertion of the state's formal monopoly of legitimate violence. The government suspended the law and legal procedures, transferred what it regarded as overly diligent police officers. Other parts of the Hindu nationalist movement openly celebrated that the Hindu community had taken revenge, and that natural justice in the form of 'blood for blood' had been exercised.

In Rakesh Sharma's award winning documentary film Final Solution (2004) we see deeply disturbing examples of all these logics: the ridiculing laughter at Muslims complaining about their plight or remarks like 'this is what happens when you insult the Hindu log'. The film, which was initially banned by the authorities, documents plenty of playful rhetoric of hate. Some local leaders invoke Hanuman and suggest that his tail had set things on fire across the state, because this is something that happens in times of danger and war. This reduces and transforms the gruesome events into an unfolding of a timeless mythical logic-something everybody knew was a lie and yet took comfort in invoking. The yatra stopped at the exact places where massacres had been committed, and where hundreds had been killed, mostly by fire.

The shamefulness, the vagueness about actual events and killings, the furtive but never open celebration of the 'victory of the Hindus' I experienced in Bombay and among Shiv Sainiks after the riots was not in evidence in Rakesh Sharma's film. On the contrary: the film documents the open celebration of death, of the dead Muslim body as a sign of the power and self-confidence of the Hindus. There was also an unprecedented celebration of the 55 'Hindu martyrs, many of them in fact not temple volunteers, and of their deaths, consumed by fire. They were the victims, sacrificed to the glory of the Hindu nation. But the response was also one of fire on a scale not seen before.

Was the wreaking of death and revenge by fire a concerted strategy? A genocidal impulse towards killing as many as possible while concealing and eradicating the evidence, the dead bodies that were burned in big fires, literally in stacks? We cannot be sure. But the events fit into a larger pattern of violence being staged and interpreted as being without visible agency, a form of violence without culpability. These acts are staged as pure events, ready for inscription of motives, agency and responsibility-so pregnant with meanings that they also call for their own mythology and causal explanations-their own political theology.

\section{Conclusion}

Fire is powerful nothingness, a threshold, a transition that has no agency of its own and yet can assume a sort of anonymous agency-as uncontrollable passion, as actual deadly fires killing people, and as signs of the presence of God and the divine in a polymorphous and inscrutable sign. Are we to understand the use of fire, arson and bombs as a form of non-discursive politics? As series of events that, like Althusser's policeman crying 'hey you' (Althusser 1984), impels interpellation and interpretation? It is the fire itself, the explosion, the dead bodies of the victims, and sometimes the bomber as well, that become signs of something that may stand behind the act itself. This is a complex semiosis, a complex series of signs without rules attached or proscriptive interpretations. While bombs are the most spectacular instantiations of this, fire is the more widespread and mundane example of a complex sign of a will, an instantiation of some historical agency, 
an imputed will of a community, a feeling of revenge or indeed a sign of outrage. Fire is a polymorphous sign, a strikingly performative and transformative emptiness that sucks interpretations into it, just like it sucks oxygen into itself. Destruction by fire seems to have its own logic, maybe even its own sovereign force conceived as punishment or an impersonal force of revenge-but never executed by anyone in particular.

\section{BIBLIOGRAPHY}

Agamben, Giorgio (1998) Homo Sacer: Sovereign Power and Bare Life (translated by D. Heller-Roazen), Stanford: Stanford University Press.

Agamben, Giorgio (2005) The State of Exception, Chicago: Chicago University Press.

Althusser, Louis (1984) Essays on Ideology, London: Verso Books.

Appadurai, Arjun (1999) ‘Dead Certainty: Ethnic Violence in the Era of Globalization', in B. Meyer and P. Geschiere (eds.), Globalization and Identity: Dialectic of Flow and Closure, Oxford: Blackwell, pp. $305-25$.

Bachelard, Gaston (1987) The Psychoanalysis of Fire, New York: Beacon Press.

Bataille, Georges (1991) The Accursed Share (Vol. II and III), New York: Zone Books.

Buford, Bill (1990) Among the Thugs, New York: Vintage

Canetti, Elias (1984) Crowds and Power, New York: Farrar, Straus and Giroux.

Chandavarkar, Raj (1998) Imperial Power and Popular Politics, Cambridge: Cambridge University Press.

Chakrabarty, Dipesh (2007) 'In the Name of Politics: Democracy and the Power of the Multitude in India', Public Culture, 19(1), pp. 35-57.

Devji, Faisal (2005) Landscapes of the Jihad: Militancy, Morality, Modernity, London: Hurst and Co.

Engineer, Asghar, A. (ed.) (1991) Mandal Commission Controversy, Delhi: Ajanta Books.

Girard, Rene (1979) Violence and the Sacred, Baltimore: Johns Hopkins University Press.

Gupta, Dipankar (1982) Nativism in a Metropolis, Delhi: Manohar Publishers.

Hansen, Thomas, B. (2001) Wages of Violence: Naming and Identity in Postcolonial Bombay, Princeton: Princeton University Press.

Hansen, T.B.; Stepputat, F. (eds.) (2005) Sovereign Bodies: Citizens, Migrants and States in the Postcolonial World, Princeton: Princeton University Press.

Hansen, T.B.; Stepputat, F. (2006) 'Sovereignty revisited', Annual Review of Anthropology, vol. 35, pp. 295-315.

Katzenstein, Mary, F. (1981) Equality and Ethnicity: Shiv Sena Party and Preferential Policies in Bombay, Ithaca: Cornell University Press.

Padgaonkar, Dilip (1993) When Bombay Burned, New Delhi: USB Publishers. 
Pandey, Gyanendra (1990) The Construction of Communalism in Colonial North India, Delhi: Oxford University Press.

Parry, Jonathan (1995) Death in Banaras, Cambridge: Cambridge University Press.

Schmitt, Carl (1985) Political Theology: Four Chapters on the Concept of Sovereignty. Cambridge, Mass. and London: MIT Press. (Translated by George Schwab), [1922].

Sen, Atreyee (2007) Shiv Sena Women: Violence and Communalism in a Bombay Slum, Bloomington: Indiana University Press.

Tambiah, Stanley (1996) Levelling Crowds: Ethnonationalist Conflicts and Collective Violence in South Asia, Berkeley: University of California Press.

Turner, Victor (1974) The Ritual Process: Structure and Anti-structure, New York: Transaction Press.

\section{NOTES}

1. I would like to thank Amélie Blom and Djallal Heuzé for their constructive criticism of an earlier version of this paper. Their comments helped me to clarify and sharpen my argument considerably.

2. See Schmitt 1922. Schmitt's work and many of its deeply problematic assumptions have in the recent decade been worked through by Giorgio Agamben $(1998,2005)$. I have applied some of this philosophical re-working to political anthropology in Hansen $(2005,2006)$.

3. I have dealt with this in extenso in my chapters on the Bombay riots and the Srikrishna Commission in Hansen (2001).

4. Quoted from Chakrabarty (2007: 54).

5. The most succinct statement of this can be found in the Mandal Commission Report that recommended that reservations were extended to the so-called $\mathrm{OBC}$ sections, Other Backward Classes, constituting app. $53 \%$ of the population. For the texts and definitions of 'community backwardness', see Engineer (1991: 290-94).

6. These events are detailed in several books such as Padgaonkar (1993), Hansen (2001), Sen (2007).

\section{ABSTRACTS}

What are we to make of the fact that most violence in India rarely has any visible or clear actors? Why is most violence represented as 'pure events' without identifiable actors-but as 'mobs', as spontaneous combustion, as spontaneous rage that arises from perceived collective grievances and insults? Why in a country saturated in political rhetoric is it that acts of violence have acquired their own semiotic register, a singular form of 'political communication'? Fire and incidents of arson are at the heart of this naturalization of violence, as events without actors. Fire is not only one of the densest cultural signifiers in India, it also is at the heart of the transgressions, the exceptions, the taboos, the sacrifices, the agency, the sense of communitas that unfold in times of heightened conflict and violent clashes with the state or other 
communities. Drawing on examples from Mumbai and elsewhere, the paper attempts to theorize and elaborate the nexus between fire, violence and collective sentiments.

INDEX

Keywords: Mumbai riots (1993), Gujarat pogroms (2002), agency, collective sentiments, communal violence, crowd action, fire (agni), irresponsibility, semiotics of violence

\section{AUTHOR}

\section{THOMAS BLOM HANSEN}

Professor of Religious Studies at the Faculty of Social and Behavioural Sciences, University of Amsterdam 